\title{
Membrane and transformation characteristics of lymphocytes isolated from the synovial membrane and paired peripheral blood of patients with rheumatoid arthritis
}

\author{
C. J. L. M. MEIJER ${ }^{1}$, L. B. A. VAN DE PUTte, ${ }^{3}$ G. J. M. LAFEbER, ${ }^{2}$ \\ E. DE HAAS, ${ }^{1}$ AND A. CATS ${ }^{2}$ \\ From the ${ }^{1}$ Departments of Pathology and ${ }^{2}$ Rheumatology, University Medical Centre, Leiden, and the \\ ${ }^{3}$ Department of Rheumatology, University Hospital Nijmegen, The Netherlands
}

SUMMARY Membrane and transformation characteristics of lymphocytes isolated from the synovial membrane and from paired peripheral blood samples, obtained from patients with classical rheumatoid arthritis, were studied. Synovial tissue lymphocytes were isolated by a new technique. Two suspensions of peripheral blood lymphocytes were studied: one isolated by Ficoll-Isopaque density gradient centrifugation, the other enriched in $\mathrm{T}$ cells by an additional step of 1 hour nylon wool column filtration. All suspensions were characterised by the percentages of mononuclear phagocytic cells, and T and B lymphocytes. The spontaneous ${ }^{3} \mathrm{H}$-thymidine uptake of synovial tissue lymphocyte suspensions always exceeded that of the peripheral blood lymphocyte suspensions. The in-vitro responsiveness of synovial tissue lymphocytes to PHA, Con-A, and PWM, as measured by ${ }^{3} \mathrm{H}-$ thymidine uptake, was always consistently lower than that of paired peripheral blood lymphocytes whether or not enriched in T cells. The responsiveness to antigens, including PPD, varidase, and an antigen cocktail consisting of varidase, trychophyton, and Staphylococcus aureus antigen, showed the same effect. No dissociation was found between the response to PPD and the other antigens studied. These results suggest that the relative unresponsiveness to mitogens and antigens of synovial tissue lymphocytes in comparison with blood lymphocytes is not caused by mononuclear phagocyte contamination, but either by different subsets of $T$ lymphocytes or by different functional states of $T$ lymphocytes present in the synovial membrane and peripheral blood of patients with rheumatoid arthritis.

The aetiology of rheumatoid arthritis and related diseases is still unknown, but it has become evident that lymphocytes play an important role in the pathogenesis of rheumatoid arthritis (Pearson et al., 1975).

Several groups have shown that mainly $\mathrm{T}$ lymphocytes are present in the rheumatoid synovial membrane (Van Boxel and Paget, 1975; Tannenbaum et al., 1975; Meijer et al., 1977) and synovial fluid (Van de Putte et al., 1976; Burmester et al., 1978). It has been suggested that $\mathrm{T}$ lymphocytes are at least partially responsible for the chronicity of the inflammatory process (Van de Putte et al., 1977).

\section{Accepted for publication 19 February 1979}

Correspondence to Dr C. J. L. M. Meijer, Department of Pathology, University Medical Centre, Postbox 9603, Wassenaarseweg 62, 2300 RC Leiden, The Netherlands.
These findings stimulated several groups to study the in-vitro mitogen and antigen responsiveness of lymphocytes isolated from the synovial fluid, synovial membrane, and peripheral blood of patients with rheumatoid arthritis (Ivanyi et al., 1973; Abrahamson et al., 1975, 1976, 1977, 1978; Loewi et al., 1975; Hepburn et al., 1976; Burmester et al. 1978).

Recently we developed a rapid and reproducible 2-step procedure for isolation of lymphocytes from chronically inflamed synovial membranes (Lafeber et al., 1978). This method ensures a high recovery of synovial tissue lymphocytes and results in cell suspensions with a high percentage of lymphocytes without selective losses of lymphocyte subpopulations, while recovery and viability of lymphocytes, as determined by trypan blue exclusion, is high. 
In the present study the in vitro mitogen and antigen responsiveness of synovial tissue lymphocytes, isolated by that method, was compared with that of paired peripheral blood lymphocytes. Peripheral blood lymphocyte suspensions were prepared both with and without a $T$ cell enrichment procedure. This was done for the sake of comparison with synovial tissue lymphocytes, since the latter have been shown to be predominantly $T$ cells. Further characterisation of these suspensions included identification of mononuclear phagocytic cells, $\mathrm{T}$ lymphocytes, and B lymphocytes.

The results suggest that the diminished ${ }^{3} \mathrm{H}$ thymidine incorporation of synovial tissue lymphocyte preparations to mitogens and antigens, when compared to paired peripheral blood lymphocytes, is not due to mononuclear phagocyte contamination but rather to differences in $\mathrm{T}$ cell characteristics.

\section{Materials and methods}

\section{PATIENTS}

Synovial membrane specimens were obtained at surgical synovectomy of the knee. All 14 patients had definite or classical rheumatoid arthritis according to the ARA criteria (Ropes et al., 1959). None of the patients was receiving corticosteroids or cytotoxic drugs, but all were being treated with nonsteroidal anti-inflammatory drugs. Synovial membranes were collected in a medium consisting of minimal essential medium (Mem) containing $20 \mathrm{mM}$ hepes buffer per $100 \mathrm{ml}$ (Flow Laboratories, UK), $4 \%$ of a penicillin-streptomycin solution $(5000 \mathrm{IU} / \mathrm{ml}$ and $5000 \mu \mathrm{g} / \mathrm{ml}$ respectively), and $20 \%$ heat-decomplemented Fetal Calf Serum (FCS), and were immediately transported to the laboratory. The histology of all synovial membranes showed variable degrees of lymphocytic and plasma cell infiltration and was compatible with the diagnosis of rheumatoid arthritis. All synovial membranes showed low numbers of B lymphocytes as detected by the IgM mouse complement coated sheep red cell (EAC) overlayer technique (Meijer and Lindeman, 1975).

Heparinised venous blood was obtained from all patients on the day of synovectomy before the operation started.

\section{TISSUE PROCESSING AND LYMPHOCYTE} ISOLATION

All tissues were processed under sterile conditions within 2 hours of the operation. Fat, fibrous tissue, and blood clots were removed from the synovial tissue before processing of the tissue. Several small pieces were embedded in Paraplast for histological evaluation (haematoxylin-eosin staining). Moreover, as a histological check on the cell isolation procedure, pieces of tissue were quickly frozen in liquid nitrogen to detect $B$ cells and mononuclear phagocytes by the EAC overlayer technique (Meijer and Lindeman, 1975). The rest of the synovial tissue was used for cell isolation studies by the 2-step isolation technique of Lafeber et al. (1978). Briefly the first step consists of enzymatic digestion of tissue fragments (10 g wet tissue per $20 \mathrm{ml}$ enzyme medium) for $30 \mathrm{~min}$ at $37^{\circ} \mathrm{C}$. This enzyme medium contains DNA-ase $1 \vec{\circ}$ $\mathrm{mg} / \mathrm{ml}$ and collagenase $2 \mathrm{mg} / \mathrm{ml}$ medium. The digested tissue fragments and cells are filtered through 2 nylon sieves with a pore size of 0.250 and $0.088 \mathrm{~mm}$ respectively, resulting in a crude cell suspension. In the second step this suspension is added to a nylon wool column $(600 \mathrm{mg}$ in $6 \mathrm{ml}$ volume of a $20 \mathrm{ml}$ plastic syringe (inner diameter $2 \mathrm{G}$ $\mathrm{cm}$ ) at $37^{\circ} \mathrm{C}$ ). The syringe is incubated for $7 \mathrm{~min}$ 을 at $37^{\circ} \mathrm{C}$ and the cells are eluted from the column with $20 \mathrm{ml}$ medium and then counted. It could be $T$

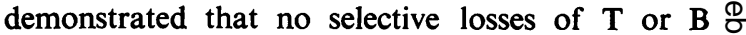
cells occur (Lafeber et al., 1978). Lymphocyte viability tested by trypan blue exclusion was always higher than $90 \%$.

Freshly drawn heparinised venous blood was layered on a Ficoll-Isopaque mixture $(d=1.07$ in order to isolate mononuclear cells by densit gradient centrifugation. One part of the mononuclear cells was directly used for marker studies and lymphocyte cultures (FI); the other part was pri- $\frac{\circ}{\circ}$ marily used for enrichment in $T$ cells by 1 hour $\varrho$ nylon wool column adherence $(\mathrm{FI}+\mathrm{N})$ (Van Oers et al., 1977). Briefly, $600 \mathrm{mg}$ nylon wool (Leucopak, 3 Fenwal Lab., Morton Grove, USA) was packed into a $20 \mathrm{ml}$ plastic syringe (Monoject, Flow, USA), filling the barrel to the $6 \mathrm{ml}$ mark. After sterilisation by an autoclave and washing the nylon wool at $37^{\circ} \mathrm{C}$ with $20 \mathrm{ml}$ medium, $30-50 \times 10^{6}$ lymphocytes in $2 \mathrm{ml}$ medium were introduced into the column 8 followed by $1 \mathrm{ml}$ medium to wash the cells into the nylon wool. The column was then sealed and in- 0 cubated at $37^{\circ} \mathrm{C}$ for 1 hour in order to remove monocytes and B lymphocytes (Julius et al., 1973; Van Oers et al., 1977). Next the non-adherent cells enriched in $T$ cells were collected by dropwise $\mathrm{N}$ elution with $25 \mathrm{ml}$ medium (prewarmed to $37^{\circ} \mathrm{C}$ ), N washed, counted, and used for marker studies and N lymphocyte cultures. Lymphocyte viability tested by trypan blue exclusion was always higher than $95 \%$.

\section{COUNTING AND IDENTIFICATION OF}

MONONUCLEAR CELLS

The percentage of lymphocytes was determined by differential counts in smears (Giemsa staining). Mononuclear phagocytic cells were identified in $\frac{\varrho}{\sigma}$ 
smears by the presence of alpha naphthyl acetate esterase activity in the cytoplasm (Yam et al., 1971). At least 500 cells were counted. It appears that 0-2\% of the cells isolated from the synovial membrane could not be classified as lymphocytes or mononuclear phagocytic cells. The very low percentages of these unclassifiable cells allowed us to exclude these cells from the differential counts and to apply a small correction, necessary to bring the sum of the percentages of lymphocytes and monocytes to 100 .

$\mathrm{T}$ lymphocytes were identified by the $\mathrm{E}$ rosette procedure and $\mathbf{B}$ lymphocytes were detected by the presence of surface membrane immunoglobulins as described by Van de Putte et al. (1976). The percentages of $\mathrm{T}$ and $\mathrm{B}$ lymphocytes were calculated with regard to the total number of lymphocytes.

\section{LYMPHOCYTE CULTURES}

Before being cultured, lymphocyte suspensions isolated from the peripheral blood and synovial tissue were incubated overnight at $37^{\circ} \mathrm{C}$ and in some instances at $4^{\circ} \mathrm{C}$. This was done because synovial tissue lymphocytes do not show mitogen responsiveness immediately after harvesting (Loewi et al., 1975). It was shown that overnight incubation at $37^{\circ} \mathrm{C}$ and $4^{\circ} \mathrm{C}$ did not led to different results in mitogen or antigen responsiveness. Lymphocytes $\left(10^{5}\right.$ cells/well) were cultured in Cooke roundbottom microtitre plates ( $220 \mathrm{M}-24 \mathrm{AR}$ ), in $150 \mu \mathrm{l}$ of medium RPMI 1640, buffered with bicarbonate, and supplemented with $20 \%$ heat inactivated human $\mathrm{AB}$ serum. Incubation was performed at $37^{\circ} \mathrm{C}$ in a humidified atmosphere of $5 \% \mathrm{CO}_{2}$ in air. The stimulants were phytohaemagglutinin (PHA) (Welcome, final concentration $50 \mu \mathrm{g} / \mathrm{ml}$ ), pokeweed mitogen (PWM) $(\mathrm{Gibco}, 50 \mu \mathrm{g} / \mathrm{ml})$, concanavalin A (con-A) (Sigma, $60 \mu \mathrm{g} / \mathrm{ml}$ ), purified protein derivate (PPD) (Rijks Instituut Volksgezondheid, Bilthoven, The Netherlands, $12.5 \mu \mathrm{g} / \mathrm{ml}$ ), and an antigen cocktail (Leguit et al., 1973) containing varidase (Lederle, $10 \mu \mathrm{g} / \mathrm{ml}$ ), trychophyton allergenic extract $(0.5 \mu \mathrm{g} / \mathrm{ml}$, Allergenen Laboratorium Haarlem, The Netherlands), and Staphylococcus aureus vaccine $(5 \mu \mathrm{g} / \mathrm{ml} \mathrm{RIV}$, Bilthoven, The Netherlands).

We analysed the response to PPD in comparison to a mixture of antigens (Leguit et al., 1973) to see whether there was a dissociation between the response to PPD and other antigens, as has been reported (Abrahamsen et al., 1976, 1978). In some patients the response to a single antigen (varidase) was investigated.

All cultures were done in triplicate. In 2 patients we investigated the possibility of an interaction between blood and synovial tissue lymphocytes; 1 of the 2 suspensions was irradiated with a dose of
$2000 \mathrm{rad}$. The observed response then reflects only proliferation of the nonirradiated population.

For PHA and Con-A stimulation the culture period was 72 hours. For stimulation by PWM, PPD, varidase, antigen cocktail and mixed lymphocyte culture a culture period of 144 hours was found to be optimal. Under these conditions the responses obtained were linearly dependent on the number of lymphocytes cultured, indicating optimal culture conditions. Twenty-four hours before harvesting the cells $0.05 \mathrm{ml}$ methyl ${ }^{3} \mathrm{H}$-thymidine solution $(40 \mu \mathrm{Ci} / \mathrm{ml})$ per well was added. Cells were harvested on glass fibre filters, and the ${ }^{3} \mathrm{H}$-thymidine incorporation was determined by counting the radioactivity on the filters in a liquid scintillation counter. The results were expressed as counts per minute (c.p.m.) per well or as transformation-index, i.e., c.p.m. after stimulation with mitogen or antigen divided by c.p.m. without mitogen or antigen. Statistical analysis was performed by Student's $t$ test.

Control experiments. In order to exclude the possible influence of the enzymes DNA-ase and collagenase on lymphocyte transformation, mitogen and antigen stimulated cultures from peripheral blood lymphocytes from healthy donors and from rheumatoid arthritis patients were performed with and without preincubation of the lymphocytes with DNA-ase and collagenase. No influence on lymphocyte transformation could be detailed.

\section{Results}

IDENTIFICATION OF LYMPHOID CELLS

Differential counts in terms of lymphocytes and mononuclear phagocytic cells and the percentages of $T$ and $B$ lymphocytes of the total number of lymphocytes are shown in Table 1. As can be seen from the Table, the 1 hour nylon wool column filtration step results in an enrichment in $\mathrm{T}$ cells and loss of B cells and mononuclear phagocytic cells. No significant differences were found between the percentages of T and B lymphocytes isolated by FI and FI $+\mathbf{N}$ from the blood of patients with rheumatoid arthritis and that of healthy donors (Table 1).

SPONTANEOUS TRANSFORMATION OF LYMPHOCYTES IN VITRO

Synovial tissue lymphocyte suspensions from rheumatoid synovial membranes showed on average a higher spontaneous ${ }^{3} \mathrm{H}$-thymidine incorporation after 3 and 6 days' culturing than lymphocytes isolated by both FI and FI $+\mathbf{N}$ from the peripheral blood from the same patients (Table 2). This was statistically significant (Student's $t$ test $\mathrm{P}<0.001$ ) for day 3. For day 6 the spontaneous ${ }^{3} \mathrm{H}$-thymidine uptake of the synovial tissue lymphocytes differed 
78 Meijer, van de Putte, Lafeber, de Haas, Cats

Table 1 Differential counts and the percentages of $T$ and $B$ lymphocytes of the cell suspensions obtained from the synovial tissue $(S T)$ and peripheral blood from 14 patients with rheumatoid arthritis

\begin{tabular}{|c|c|c|c|c|c|c|c|c|}
\hline \multirow{3}{*}{ Rheumatoid arthritis } & \multicolumn{4}{|c|}{ Differential counts } & \multicolumn{4}{|c|}{ Lymphocyte subpopulations } \\
\hline & \multicolumn{2}{|c|}{ Lymphocytes* (\%) } & \multicolumn{2}{|c|}{$M \varnothing^{*}(\%)$} & \multicolumn{2}{|c|}{$E R F C^{* *}(\%)$} & \multicolumn{2}{|c|}{ slg Bearing ly** $(\%)$} \\
\hline & Mean & Range & Mean & Range & Mean & Range & Mean & Range \\
\hline $\begin{array}{l}\text { Blood ly (FI) } \\
\text { Blood ly (FI+N) } \\
\text { ST ly }\end{array}$ & $\begin{array}{l}89 \\
96 \\
81\end{array}$ & $\begin{array}{l}(78-98) \\
(94-97) \\
(68-95)\end{array}$ & $\begin{array}{r}11 \\
4 \\
19\end{array}$ & $\begin{array}{l}(2-21) \\
(2-6) \\
(13-28)\end{array}$ & $\begin{array}{l}70 \cdot 3 \\
84 \cdot 5 \\
89 \cdot 0\end{array}$ & $\begin{array}{l}(67-74) \\
(77-90) \\
(78-96)\end{array}$ & $\begin{array}{l}9 \cdot 3 \\
1 \cdot 9 \\
2 \cdot 0\end{array}$ & $\begin{array}{l}(7-12) \\
(1-4) \\
(1-4)\end{array}$ \\
\hline $\begin{array}{l}\text { Controls } \\
\text { Blood ly }(F I) n=21 \\
\text { Blood ly }(F I+N) n=5\end{array}$ & $\begin{array}{l}86 \\
95\end{array}$ & $\begin{array}{l}(74-95) \\
(93-98)\end{array}$ & $\begin{array}{r}14 \\
5\end{array}$ & $\begin{array}{l}(5-26) \\
(2-7)\end{array}$ & $\begin{array}{l}72 \cdot 7 \\
85 \cdot 6\end{array}$ & $\begin{array}{l}(63-78) \\
(76-91)\end{array}$ & $\begin{array}{r}10 \cdot 8 \\
1 \cdot 1\end{array}$ & $\begin{array}{l}(6-15) \\
(1-3)\end{array}$ \\
\hline
\end{tabular}

ly $=$ Lymphocytes. $\mathbf{M} \varnothing=$ mononuclear phagocytic cells. FI = Ficoll-Isopaque. $\mathbf{F I}+\mathbf{N}=$ Ficoll-Isopaque +1 hour nylon wool column adherence ERFC = Lymphocytes forming rosettes with uncoated sheep erythrocytes (E). slg =Surface membrane immunoglobulins. $n=$ Numbers of healthy donors studied. * = Calculated for the total number of cells (see 'Methods'). ** Calculated for the total number of lymphocytes (see 'Methods').

Table 2 Spontaneous ${ }^{3} \mathrm{H}$-thymidine uptake of lymphocytes (ly) isolated from the synovial tissue (ST) and peripheral blood of patients with rheumatoid arthritis

\begin{tabular}{|c|c|c|c|c|c|c|}
\hline \multirow[t]{2}{*}{ Rheumatoid arthritis } & \multicolumn{3}{|c|}{3 day's culture } & \multicolumn{3}{|c|}{6 day's culture } \\
\hline & Mean & Range & $n$ & Mean & Range & $n$ \\
\hline
\end{tabular}

For abbreviations see footnotes to Table 1 . Results are expressed as counts per minute $\times 10^{3} /$ well.

Table 3 Mitogen responses of lymphocyte suspensions calculated as mean transformation index*

\begin{tabular}{|c|c|c|c|c|c|c|}
\hline Rheumatoid arthritis & $n$ & $P H A$ & $n$ & con-A & $n$ & $P W M$ \\
\hline Blood ly (FI) & 8 & $\begin{array}{l}155 \cdot 5 \\
(69 \cdot 2-295 \cdot 0)\end{array}$ & 9 & $\begin{array}{l}31 \cdot 6 \\
(11 \cdot 9-79 \cdot 5)\end{array}$ & 9 & $\begin{array}{l}52 \cdot 9 \\
(19 \cdot 2-121 \cdot 7)\end{array}$ \\
\hline Blood ly $(F I+N)$ & 10 & $\begin{array}{l}176 \cdot 3 \\
(78 \cdot 1-321 \cdot 8)\end{array}$ & 9 & $\begin{array}{l}30 \cdot 4 \\
(7 \cdot 1-58 \cdot 7)\end{array}$ & 7 & $\begin{array}{l}148 \cdot 8 \\
(88 \cdot 5-321 \cdot 7)\end{array}$ \\
\hline ST ly & 8 & $\begin{array}{l}10 \cdot 8 \\
(1 \cdot 2-25 \cdot 6)\end{array}$ & 9 & $\begin{array}{l}3 \cdot 6 \\
(1 \cdot 0-9 \cdot 2)\end{array}$ & 7 & $\begin{array}{c}4 \cdot 2 \\
(1 \cdot 0-14 \cdot 2)\end{array}$ \\
\hline $\begin{array}{l}\text { Controls } \\
\text { Blood ly (FI) }\end{array}$ & 15 & $\begin{array}{l}132 \cdot 9 \\
(54 \cdot 2-301 \cdot 7)\end{array}$ & 15 & $\begin{array}{l}38 \cdot 4 \\
(10 \cdot 8-88 \cdot 6)\end{array}$ & 15 & $\begin{array}{l}47 \cdot 8 \\
(29 \cdot 1-112 \cdot 7)\end{array}$ \\
\hline Blood ly $(F I+N)$ & 6 & $\begin{array}{l}168 \cdot 4 \\
(76 \cdot 2-310 \cdot 2)\end{array}$ & 5 & $\begin{array}{l}29 \cdot 8 \\
(8 \cdot 2-60 \cdot 3)\end{array}$ & 5 & $\begin{array}{l}136 \cdot 7 \\
(72 \cdot 5-289 \cdot 2)\end{array}$ \\
\hline
\end{tabular}

Transformation index $=\frac{\text { c.p.m. } / \text { well after stimulation with mitogen. }}{\text { c.p.m. } / \text { well without mitogen. }}=$ Phytohaemagglutinin, con $-\mathbf{A}=$ concanavalin $\mathbf{A}, \mathbf{P W M}=$ pokeweed mitogen. *Numbers in brackets indicate the range of transformation indices. For other abbreviations see footnotes to Table 1.

significantly only from that of the T-cell-enriched peripheral blood lymphocyte suspension $(\mathrm{P}<0 \cdot 001)$ (Table 2). Moreover, the T-cell-enriched peripheral blood lymphocyte suspension showed on day 6 a significantly $(\mathrm{P}<0 \cdot 01)$ lower ${ }^{3} \mathrm{H}$-thymidine uptake than the peripheral blood lymphocyte suspension isolated by FI.

\section{IN VITRO RESPONSE TO MITOGENS}

Stimulation of synovial tissue lymphocytes with PHA, con-A, and PWM (Tables 3 and 4) always showed a definite but variable response.

The response of synovial tissue lymphocytes to the mitogens used was always consistently lower than that of the paired peripheral blood lymphocytes, isolated by both FI and FI + N (Table 3)

Although the response to PWM, expressed as transformation index, of the T-cell-enriched rheumatoid peripheral blood lymphocytes $(148 \cdot 8)$ was higher than that of the FI-isolated peripheral blood lymphocytes (52.9), the PWM response, expressed as c.p.m. per well, did not differ significantly for both suspensions. This was due to the fact that the spontaneous ${ }^{3} \mathrm{H}$-thymidine incorporation of the T-cell-enriched peripheral blood lymphocyte fraction was always lower than that of the FIisolated blood lymphocytes (Table 2). The same effect was found for T-cell-enriched peripheral blood 
Table 4 Responses of lymphocyte suspensions of 5 patients with rheumatoid arthritis to varidase, purified protein derivate (PPD), antigen cocktail, and pokeweed mitogen (PWM), calculated as counts per minute (c.p.m.) $\times 10^{3} /$ well and as transformation index $(T I)$

\begin{tabular}{|c|c|c|c|c|c|c|c|c|c|}
\hline \multirow[t]{2}{*}{ Patients } & & \multicolumn{2}{|c|}{ Varidase } & \multicolumn{2}{|l|}{$P P D$} & \multicolumn{2}{|c|}{ Antigen cocktail } & \multicolumn{2}{|l|}{$P W M$} \\
\hline & & c.p.m. & $T I$ & c.p.m. & $T I$ & c.p.m. & $T I$ & c.p.m. & $T I$ \\
\hline \multirow[t]{3}{*}{1} & FI & \multicolumn{2}{|r|}{ NT } & $64 \cdot 8$ & $22 \cdot 3$ & $37 \cdot 3$ & $12 \cdot 9$ & $78 \cdot 0$ & $26 \cdot 8$ \\
\hline & $\mathbf{F I}+\mathbf{N}$ & $40 \cdot 0$ & $72 \cdot 3$ & $54 \cdot 7$ & $98 \cdot 9$ & $51 \cdot 6$ & $93 \cdot 2$ & $62 \cdot 0$ & $112 \cdot 1$ \\
\hline & ST & $2 \cdot 4$ & $1 \cdot 1$ & $3 \cdot 5$ & 1.6 & $2 \cdot 4$ & $1 \cdot 1$ & $6 \cdot 6$ & 3.0 \\
\hline \multirow[t]{3}{*}{2} & FI & \multicolumn{2}{|r|}{ NT } & $4 \cdot 1$ & $2 \cdot 7$ & $3 \cdot 2$ & $2 \cdot 1$ & $46 \cdot 3$ & 30.6 \\
\hline & $\mathbf{F I}+\mathbf{N}$ & \multirow{2}{*}{\multicolumn{2}{|c|}{$\begin{array}{l}\text { NT } \\
\text { NT }\end{array}$}} & $2 \cdot 7$ & $2 \cdot 1$ & $3 \cdot 3$ & $2 \cdot 5$ & $48 \cdot 8$ & $38 \cdot 1$ \\
\hline & ST & & & $5 \cdot 8$ & $3 \cdot 2$ & $4 \cdot 8$ & $2 \cdot 7$ & $9 \cdot 3$ & $5 \cdot 1$ \\
\hline \multirow[t]{2}{*}{3} & $\mathbf{F I}+\mathbf{N}$ & \multicolumn{2}{|r|}{ NT } & $10 \cdot 6$ & $11 \cdot 8$ & $14 \cdot 1$ & $15 \cdot 7$ & $38 \cdot 1$ & $42 \cdot 6$ \\
\hline & ST & \multicolumn{2}{|r|}{ NT } & $8 \cdot 7$ & $2 \cdot 7$ & $7 \cdot 0$ & $2 \cdot 1$ & 10.4 & $3 \cdot 1$ \\
\hline \multirow[t]{2}{*}{4} & $\mathbf{F I}+\mathbf{N}$ & $5 \cdot 2$ & $6 \cdot 1$ & $6 \cdot 2$ & $7 \cdot 3$ & $8 \cdot 1$ & 9.4 & $84 \cdot 2$ & $98 \cdot 6$ \\
\hline & ST & $5 \cdot 0$ & 1.0 & $5 \cdot 3$ & $1 \cdot 2$ & $5 \cdot 6$ & $1 \cdot 1$ & $6 \cdot 3$ & $1 \cdot 2$ \\
\hline \multirow[t]{3}{*}{5} & FI & $8 \cdot 5$ & $2 \cdot 8$ & $90 \cdot 1$ & $27 \cdot 3$ & 21.4 & $6 \cdot 5$ & $64 \cdot 0$ & 19.2 \\
\hline & $\mathbf{F I}+\mathbf{N}$ & $8 \cdot 4$ & $12 \cdot 0$ & 119.8 & $171 \cdot 1$ & $71 \cdot 5$ & $102 \cdot 2$ & 76.9 & 109.9 \\
\hline & ST & $5 \cdot 2$ & $1 \cdot 2$ & $15 \cdot 8$ & $3 \cdot 5$ & $6 \cdot 3$ & 1.4 & 63.9 & $14 \cdot 2$ \\
\hline
\end{tabular}

FI, FI+N see footnotes to Table 1. For antigen concentration and composition antigen cocktail see 'Material and methods'. NT $=$ Not tested.

lymphocytes from healthy donors. No significant differences were observed between the mitogen response of peripheral blood lymphocytes from patients with rheumatoid arthritis and that of the peripheral blood lymphocytes from healthy donors (Table 3). Studies of the dose response and time response of the lymphocyte transformation of synovial tissue lymphocytes showed no differences as compared to peripheral blood lymphocytes from patients with rheumatoid arthritis and from healthy donors.

\section{IN VITRO RESPONSE TO ANTIGENS}

In general the response of synovial tissue lymphocytes to PPD, varidase, and a mixture of antigens was low (Table 4) when compared to the response of peripheral blood lymphocytes.

The response of synovial tissue lymphocytes to the antigen cocktail and PPD showed no significant differences. In the cases tested the response to varidase equalled the response to the antigen cocktail. Varying the concentration of PPD $(10 \mu \mathrm{g}-$ $200 \mu \mathrm{g}$ ) and the number of days of culture (3-8 days) in patients 1,3 , and 5 revealed that the optimum culture conditions were the same as for peripheral blood lymphocytes. The responsiveness of synovial tissue lymphocytes to PPD was lower in 4 patients $(1,3,4$, and 5$)$ and higher in 1 patient (2) than that of the peripheral blood lymphocytes.

\section{AUTOLOGOUS MIXED LYMPHOCYTE CULTURE}

One-way mixed lymphocyte cultures with irradiated synovial tissue lymphocytes as stimulator cells and peripheral blood lymphocytes as responder cells or the reverse did not result in an increased ${ }^{3} \mathrm{H}$ thymidine incorporation. This indicates that no newly formed stimulating antigen is present on synovial tissue lymphocytes.

\section{Discussion}

We have shown that the responsiveness of rheumatoid synovial tissue lymphocytes to PHA, con-A, and PWM was always lower than that of the peripheral blood lymphocytes from these patients. This is an agreement with others (Abrahamsen et al., 1977; Loewi et al., 1975). The low responsiveness of synovial tissue lymphocytes to PHA and con-A is remarkable, since it is known that these mitogens stimulate predominantly $\mathbf{T}$ lymphocytes (Greaves and Janossy, 1972).

The fact that PWM is capable of inducing transformation of relatively pure suspensions of synovial T lymphocytes is not surprising, since this phenomenon has been previously reported with pure $T$ lymphocyte suspensions (Chess et al., 1974).

The differences in spontaneous ${ }^{3} \mathrm{H}$-thymidine uptake and lymphocyte responsiveness to mitogens and antigens between the lymphocyte suspensions derived from synovial tissue and paired peripheral blood might be explained by the presence of mononuclear phagocytes in these suspensions, since these cells can modify lymphocyte transformation (Scott, 1972). However, the fact that a 1-hour nylon wool column filtration step of synovial tissue cell suspensions, which decreases the number of mononuclear phagocytic cells from $14 \%$ to $5 \%$, does not seriously affect the lymphocyte proliferative response (Meijer, unpublished data) does not favour this explanation.

The transformation of synovial tissue lymphocytes to PPD did not differ significantly from the response induced by a combination of antigens or varidase and was in general low (Table 4). This low response is in agreement with similar results obtained with synovial fluid lymphocytes (Ivanyi et al., 1973; Burmester et al., 1978) and obtained with the 
synovial tissue lymphocytes from patients with juvenile rheumatoid arthritis (Abrahamsen et al., 1977).

The lack of dissociation of responsiveness to PPD and the antigen cocktail is in contrast to the findings of Abrahamsen et al., $(1976,1978)$ obtained with synovial fluid and synovial tissue lymphocytes from patients with classical rheumatoid arthritis. This difference may be explained by the higher purity and viability of our synovial tissue lymphocyte suspensions. As the low response of synovial tissue lymphocytes is unlikely to be due to mononuclear phagocytic cells, it is reasonable to ascribe the reduced transformation found, to the nature of the $T$ lymphocyte populations present in the synovial membrane. One possible explanation is the presence of different subsets of $T$ cells in the synovial membrane and blood of RA patients. A similar explanation has been given for the different response to PHA and con-A of murine thymus and spleen lymphocyte populations (Stobo et al., 1972). Arguments in support of this assumption come from Leeuwen et al. (1976), De Vries et al. (1977), and Burmester et al. (1978). Burmester et al. claimed an increase of suppressor $T$ cells in rheumatoid synovial fluid compared to peripheral blood. Van Leeuwen et al. (1976) and De Vries et al. (1977) have shown that in the rheumatoid synovial fluid and synovial membrane a morphologically recognisable subset of $T$ cells was found, which is absent or present in low numbers in the peripheral blood of patients with rheumatoid arthritis (De Vries, personal communication). They called these cells 'atypical' or 'cerebriform' mononuclear cells. Another explanation is that the lymphoid cells present in the synovial membrane or synovial fluid are already activated. The higher spontaneous ${ }^{3} \mathrm{H}$ thymidine uptake of synovial tissue lymphocytes observed at days 3 and 6 as compared to peripheral blood lymphocytes favours this explanation. The activating effect of synovial fluid on autologous peripheral blood lymphocytes in rheumatoid arthritis (Sebök et al., 1977) is also compatible with this explanation.

In conclusion, our results suggest that the relative unresponsiveness of synovial tissue lymphocytes to polyclonal mitogens and antigens is caused either by different subsets of $\mathrm{T}$ lymphocytes or a different functional state of $\mathrm{T}$ lymphocytes present in the synovial membrane and peripheral blood of patients with rheumatoid arthritis.

We are indebted to the orthopaedic surgeons G. J. van de Bas, H. J. de Mol van Otterloo, L. J. C. D. Mol, H. W. Wouters, and the staff of the Zeehospitium Den Haag, the orthopaedic department of the Daniël de Hoed kliniek Rotterdam, and the department of the orthopaedic surgery,
University Medical Centre, Leiden, for the help we received in obtaining the tissue and blood samples of the patients we studied. We thank Mrs M. Damsteeg for excellent technical assistance, Mrs. C. Zock for typing the manuscript, and Dr J. D. Macfarlane for his help in the preparation of the manuscript.

\section{References}

Abrahamsen, T. G., Fröland, S. S., Natvig, J. B., and Pahle, J. (1975). Elution and characterization of lymphocytes from rheumatoid inflammatory tissue. Scandinavian Journal of Immunology, 4, 823-830.

Abrahamsen, T. G., Fröland, S. S., Natvig, J. B., and Pahle, J. (1976). Antigen and unspecific mitogen stimulation of lymphocytes eluted from rheumatoid inflammatory tissue. Scandinavian Journal of Immunology, 5, 1057-1063.

Abrahamsen, T. G., Fröland, S. S., Natvig, J. B., and Pahle, J. (1977). Lymphocytes eluted from synovial tissue of juvenile rheumatoid arthritis patients. Arthritis and Rheumatism, 20, 772-778.

Abrahamsen, T. G., Fröland, S. S., and Natvig, J. B. (1978). In vitro mitogen stimulation of synovial fluid lymphocytes from rheumatoid arthritis and juvenile rheumatoid arthritis patients: dissociation between the response to antigen and polyclonal mitogens. Scandinavian Journal of Immunology, 7, 81-90.

van Boxel, J. A., and Paget, S. A. (1975). Predominantly $\mathrm{T}$ cell infiltrate in rheumatoid synovial membranes. New England Journal of Medicine, 293, 517-520.

Burmester, G. R., Kalden, J. R., Peter, H. H., Schedel, IO Beck, P., and Wittenborg, A. (1978). Immunologica and functional characteristics of peripheral blood and synovial fluid lymphocytes from patients with rheumatoi arthritis. Scandinavian Journal of Immunology, 7, 405-417.

Chess, L., MacDermott, R. P., and Schlossman, S. F. (1974). Immunological functions of isolated human lymphocyte subpopulations. I. Quantitative isolation on human $T$ and B cells and response to mitogens. Journal of Immuno$\log y, 113,1113-1122$.

Greaves, M., and Janossy, G. (1972). Elicitation of selective $T$ and $B$ lymphocyte responses by cell surface binding ligands. Transplantation Reviews, 11, 87-130.

Hepburn, B., MacDuffie, F. C., and Rits, R. E. (1976). Impaired blastogenic response of lymphocytes from synovial fluids and peripheral blood of patients with rheumatoid arthritis. Journal of Rheumatology, 3, 118-123.

Ivanyi, L., Lehner, T., and Burry, H. C. (1973). The response of synovial fluid lymphocytes to $\mathrm{T}$ and $\mathrm{B}$ stimulants in vitro. Immunology, 25, 905-908.

Julius, M. H., Simpson, E., and Herzenberg, L. A. (1973). A rapid method for the isolation of functional thymus derived murine lymphocytes. European Journal of Immuno$\log y, 3,645-649$.

Lafeber, G. J. M., Van de Putte, L. B. A., and Meijer, C. J. L. M. (1978). Lymphocyte isolation from chronically inflamed synovial membranes. Journal of Immunological Methods, 19, 361-367.

Leeuwen, A. W. F. M. van, Meijer, C. J. L. M., Van de Putte, L. B. A., De Vries, E., and Man, J. C. H. de (1976). Sézary type cells in rheumatoid synovial fluid, Lancet, 1 , 248-249.

Leguit, P., Meinesz, A., Huismans, L., and Eysvogel, V. P. (1973). The use of an antigen cocktail in the lymphocyte transformation test. Clinical and Experimental Immunology, 14, 149-152.

Loewi, G., Lance, E. M., and Reynolds, G. (1975). Study of lymphoid cells from inflamed synovial membranes. Annals of the Rheumatic Diseases, 34, 524-528. 
Meijer, C. J. L. M., and Lindeman, J. (1975). A modified method for tissue localization of cells bearing a complement receptor. Journal of Immunological Methods, 9, 59-69.

Meijer, C. J. L. M., Van de Putte, L. B. A., Eulderink, F., Kleinjan, R., Lafeber, G. J. M., and Bots, G. Th. A. M. (1977). Characteristics of mononuclear cell populations in chronically inflammed synovial membranes. Journal of Pathology, 121, 1-8.

van Oers, M. H. J., Zeylemaker, W. P., and Schellekens, P. Th. A. (1977). Separation and properties of EA rosette forming lymphocytes in humans. European Journal of Immunology, 7, 143-150.

Pearson, C. M., Paulus, H. E., and Mackleder, H. (1975). The role of the lymphocyte and its products in the propagation of joint disease. Annals of the New York Academic Sciences, 256, 150-168.

Putte, L. B. A. van de, Meijer, C. J. L. M., Lafeber, G. J. M., Kleinjan, R., and Cats, A. (1976). Lymphocytes in rheumatoid and non-rheumatoid synovial fluids. Annals of the Rheumatic Diseases, 35, 451-455.

Putte, L. B. A. van de, Vries, E. de, Leeuwen, A. W. F. M. van, and Meijer, C. J. L. M. (1977). T lymphocytes and rheumatoid inflammation p. 103-110. In Non-articular Forms of Rheumatoid Arthritis. Edited by T. E. W. Feltkamp. Stafleu Scientific Publishing Company: Leiden.

Ropes, M. W., Bennet, G. A., and Cobb, S. (1959). Diag- nostic criteria for rheumatoid arthritis; 1958 revision. Annals of the Rheumatic Diseases, 18, 49-54.

Scott, M. T. (1972). Biological effects of the adjuvant Coryne bacterium parvum I. Inhibition of DNA mixed lymphocyte and GVH reactivity. Cellular Immunology, 5, 419-426. Sebök, J., Talerman, A., Wouters, H. W., and Lems, P. H. (1977). The activating effect of synovial fluid and washings of synovial membrane on autologous lymphocytes in rheumatoid arthritis. Arthritis and Rheumatism, 20, 13501353.

Stobo, J. D., Rosenthal, A. S., and Paul, W. E. (1972). Functional heterogeneity of murine lymphoid cells. I. Responsiveness to and surface binding of concanavalin A and phytohemagglutinin. Journal of Immunology, 108, $1-17$.

Tannenbaum, H., Pinkus, G. S., Anderson, L. G., and Schur, P. H. (1975). Immunologic characterization of the mononuclear cell infiltrates in rheumatoid nodules and in lip biopsies from patients with Sjögren's syndrome. Arthritis and Rheumatism, 18, 305-314.

Vries, E. de, Leeuwen, A. W. F. M. van, Putte, L. B. A. van de, Lafeber, G. J. M., and Meijer, C. J. L. M. (1977). Atypical $\mathbf{T}$ cells in rheumatoid synovial membranes. Virchows Archiv B: Cell Pathology, 24, 19-26.

Yam, L. T., Le, C. U., and Crosby, W. H. (1971). Cytochemical identification of monocytes and granulocytes. American Journal of Clinical Pathology, 55, 283-290. 